\title{
Customer Saving Satisfaction Viewed from the Customer's Perspective: A Study on Islamic Banks in the Special Region of Yogyakarta
}

Widyarini

Universitas Islam Negeri Sunan Kalijaga, Yogyakarta, Indonesia

Email: widyarini@uin-suka.ac.id

Syamsul Hadi

Universitas Islam Indonesia, Yogyakarta, Indonesia

Article History:

\begin{tabular}{|l|l|}
\hline Received: September 25, 2020 & Accepted: June 29, 2021 \\
\hline Revised: June 9, 2021 & \\
\hline
\end{tabular}

\section{Abstract}

Technological developments already change the behavior of employee salary payments. This is done to reduce the risk of carrying large amounts of cash, speeding up the payment process and reduce the working time of the finance department. Sometimes a spesific bank appointment does not make employees feel satisfied for several reasons, such as: already a customer from another bank, forced to open a new account, short of bank facilities (ATMs), ATM the location is far from his or her the house. The purpose of the research is to find out the difference in customer satisfaction levels of saving customers reviewed from the beginning of bank account opening, termed 'Voluntary Customer' or 'Forced Customer'. This research is a field study with the population of Saving Customers in Sharia Bank operating in the Special Region of Yogyakarta. Samples are taken by snowball sampling method. The number of samples that met the requirements was 394 consist of 'Voluntary Customer' as many as 247 respondents and 'Forced Customer' as many as 147 respondents. The questionnaire was set in five points Likert scales. Validity Test using Product Moment Correlation and 
Reliability Test using Chronbah Alpha. The results of the study are as follows: 1). Customer satisfaction of Sharia Bank is still very low. 2). There is a significant difference between the satisfaction of 'Voluntary Customer' and 'Forced Customer'. 3) There is a significant difference between the satisfaction of 'Voluntary Customers who know the contract' and 'Forced Customers who do not know the contract'. 4). There is no significant difference between the satisfaction of 'Voluntary Customer who knows the contract' and 'Voluntary Customer who does not know the contract'. 5). There is no significant difference between the satisfaction of 'Forced Customer who knows the contract' and 'Forced Customer who does not know the contract'. 6). There is no significant difference between the satisfaction of 'Voluntary Customers who do not know the contract' and the 'Forced Customer who knows the contract'.

\title{
Keywords: Corporate Cooperation, 'Savings Customer, 'Voluntary Customer' and 'Forced Customer'
}

\begin{abstract}
Abstrak
Perkembangan teknologi telah mampu mengubah perilaku pembayaran gaji karyawan. Hal ini dilakukan guna mengurangi risiko membawa uang tunai dalam jumlah besar, kepraktisan dan mempercepat proses pembayaran kepada karyawan dan mengurangi waktu kerja bagian keuangan. Ternyata penunjukan bank oleh korporasi tidak membuat karyawan merasa puas karena beberapa alasan, antara lain: sudah menjadi nasabah dari bank lain, terpaksa membuka rekening baru, fasilitas bank (ATM) kurang, tidak menyebar dan jauh dari lokasi rumah. Tujuan penelitian adalah untuk mengetahui perbedaan tingkat kepuasan nasabah penabung ditinjau dari awal pembukaan rekening bank, diistilahkan dengan 'Nasabah Sukarela' dengan 'Nasabah Terpaksa'. Penelitian ini merupakan penelitian lapangan dengan populasi Nasabah Penabung di Bank Syariah yang beroperasi di Daerah Istimewa Yogyakarta. Sampel diambil dengan metode snowball sampling. Jumlah sampel yang memenuhi persyaratan untuk diolah sebanyak 394 yang terdiri dari 'Nasabah Sukarela' sebanyak 247 responden dan 'Nasabah Terpaksa' sebanyak 147 responden. Alternatif jawaban
\end{abstract}


kuesioner menggunakan skala Likert dengan skala satu sampai dengan lima. Uji Validitas menggunakan Korelasi Product Moment dan Uji Reliabilitas menggunakan Chronbah Alpha. Hasil penelitian adalah sebagai berikut: 1). Kepuasan nasabah Bank Syariah masih sangat rendah. 2). Terdapat perbedaan secara signifikan antara kepuasan 'Nasabah Sukarela' dengan 'Nasabah Terpaksa'. 3)Terdapat perbedaan secara signifikan antara kepuasan 'Nasabah Sukarela yang tahu akad' dengan 'Nasabah Terpaksa yang tidak tahu akad'. 4). Tidak terdapat perbedaan yang signifikan antara kepuasan 'Nasabah Sukarela yang tahu akad' dengan 'Nasabah Sukarela yang tidak tahu akad'. 5). Tidak terdapat perbedaan yang signifikan antara kepuasan 'Nasabah Terpaksa yang tahu akad' dengan 'Nasabah Terpaksa yang tidak tahu akad'. 6). Tidak terdapat perbedaan yang signifikan antara kepuasan 'Nasabah Sukarela yang tidak tahu akad' dengan 'Nasabah Terpaksa yang tahu akad'.

Kata Kunci: Kerjasama Korporasi, 'Nasabah Penabung', 'Nasabah Sukarela' dan 'Nasabah Terpaksa' 


\section{INTRODUCTION}

Technological developments have caused positive and negative changes in human behavior, including in business and non-business institutions. For instance, it is used by corporations in fields, such as paying employee salaries through banks. The salary is paid through collaboration between corporations and certain banks to reduce risk and practicality. Furthermore, the benefits for the Institution include reducing the risk of saving and taking money and accelerating monthly salary payments. Similarly, banks benefit through an increased number of customers within a short period and take advantage of the saved or settled funds from the Institution's employees' salaries. Not all monthly employee salaries are taken directly, but some are saved to be taken when needed.

This good cooperation does not always receive a positive response from the employees of the Institutions involved. Problems arise when most employees are against the Bank appointed by the Institution due to many reasons. For instance, employees of other banks may be dissatisfied with the work pattern. Therefore, it becomes a separate problem with the obligation to become a bank customer for salary transfers exclusive of the employee's preferred Bank.

Becoming a bank's customer is subject to administrative fees, and it is not a problem when the employee is only a customer. Problems arise when they become customers of several banks, increasing administrative costs, especially for employees with lowermiddle social class. However, there are no administration fees when checking accounts (for conventional) or wadiah contracts (for Islamic banks). The same applies when the monthly income is small, but one must be a customer of several banks. 
This collaboration leads some employees to open a new account at the designated Bank, creating a sense of being 'forced' to open a savings account. The condition applies to both conventional and Islamic banks. Moreover, the leaders' selections that their employees are unhappy with reduce satisfaction levels and result in negative word of mouth. This should be overcome with the right strategy by the management, whose main goal is to maintain and increase membership through customer satisfaction. Another problem is when the leadership chooses an Islamic Bank not liked by employees for various reasons. These reasons include facilities with limited ATMs, some of which cannot be used for transactions in all retail stores or located far from home. Also, employees may be unsure whether Islamic banks are syar' $i$ or there is no difference between profit sharing and interest. Therefore, this research shows the difference in satisfaction between Forced and Voluntary Customers at Islamic banks.

Research on customer satisfaction of Islamic Banks does not differentiate between financing and saving customers. ${ }^{1}$ The determinants and level of satisfaction in financing customers differ from funding. Financed customers are satisfied when the proposed funding is fully approved and received immediately. A poor image is created when services are provided late, or Islamic bank officers

${ }^{1}$ Examples of research included in this group include: Sarwani, Andry Herawati and Liling Listyawati, Analisis Perbandingan Kepuasan Nasabah Bank Syariah Dengan Bank Umum Konvensional di Surabaya, http://repository.unitomo.ac.id/744/, 2017.; Yudi Siyamto, Preferensi Kepuasan Nasabah Bank Umum Syariah dan Bank Umum Konvensional Dalam Perspektif Fuzzy Carter Dan Fuzzy Servqual di Surakarta, 2015, Thesis IAIN Surakarta; Abdel Fattah Mahmoud Al-Azzam, The Impact of Service Quality Dimesions on Customer Satisfaction: A Field Study of Arab Bank in Irbid City, European Journal of Business and Management vol 7, 2015; Jafar Hashemi dan Fatemeh Abbasi, The Impact of EService Quality On Customer Satisfaction, Kuwait Chapter of the Arabian Journal of Business and Management Review Volume: 3, Issue: 6A, 2014, 86-94. 
disappear immediately after hearing the financing approval. In contrast, saving customers are concerned about service issues. In this case, a bad image due to poor service does not disappear after successfully withdrawing their savings. Subsequently, the results that mix funding and financing customers are biased, meaning that these two groups should be analyzed separately. Research by separating funding and financing include SiewPeng Lee and Sedigheh Moghavvemi. ${ }^{2}$

This research separates funding and financing customers. Also, it separates funding customers based on their reasons because voluntary and forced customers have different characteristics. Furthermore, Voluntary Customers have a higher tolerance than Forced Customers. ${ }^{3}$

\section{THEORETICAL FRAMEWORK}

\section{Consumer Behavior}

Consumer behavior has a broad meaning because consumers may have several goals in carrying out one action. For instance, being a customer of an Islamic Bank is seen in function and many purposes, such as showing prestige, image, obeying religious orders, or a mandatory need. According to Schiffman, Kanuk, and Wisenblit in Fandi Tjiptono, consumer behavior is shown by their searching for, buying, using, evaluating, and shunning products and services

2 SiewPeng Lee and Sedigheh Moghavvemi, The Dimension of Service Quality and Its Impact on Customer Satisfaction, Trust and Loyalty: A Case of Malaysian Banks, Asian Jurnal of Busines and Accounting, 8(2), 2015, 91-101.

${ }^{3}$ Widyarini, Pengaruh Langsung Trust, Religiusitas dan Mediasi Perceived Value Terhadap Kepuasan Nasabah Pemabung, Disertasi. Program Pasca Sarjana UIN Sunan Kalijaga, Yogyakarta, 2020, pg 193. 
that satisfy their needs. ${ }^{4}$ This understanding shows that behavior is strongly affected by many factors in obtaining satisfaction.

Ajzen and Fishbein in Ujang Sumarman developed the Theory of Reasoned Action or Theory of Behavioral Intention (Theory of Reasoned Attitude). The theory emphasized the attitude towards an object and not strongly related to its behavior. This model integrated cognitive, affective, and konactive components. Cognitive is the description and perception of the object of attitude, while affective describes a person's feelings and emotions towards a product or brand. Furthermore, konactive shows real behavior of expressing the desire to purchase (intention to buy). Therefore, buying a product is determined by a strong desire or tendency to act because of trust. ${ }^{5}$

Consumption behavior is dynamic, though the basic principle as a reference remains the same. Therefore, a person's behavior adapts to the times, including changes in technology, religion, culture, and the environment. Similarly, customers in Indonesia could choose conventional or Islamic banks or both.

\section{Differences in Customer Characteristics}

Qualitative and quantitative research on behavior needs support from the respondent's profile. Each group could have different characteristics. The more detailed the data about the profile, the easier it is for bank management to take strategies to provide satisfaction to their customers.

Bank customers are divided into depositors (savers) and borrowers (financing) with very different characteristics. In this regard, financing customers need funds for various urgent purposes.

4 Fandi Tjiptono, Pemasaran Jasa, Prinsip, Penerapan, Penelitian, (Yogyakarta: Penerbit Andi, 2014), 50.

${ }^{5}$ Ujang Sumarman, Perilaku Konsumen, Teori dan Penerapannya dalam Pemasaran, (Bogor: Penerbit Ghalia Indonesia, 2011), pg . 177 
However, the unfavorable treatment received during the administration does not prevent canceling the intention, meaning the customers must remain patient. The various requirements taken motivate customers to accept any outcome for the service. However, the conditions are different from customers that initiate demand, savings, and time deposits. Sensitivity to services received from Customer Service (CS) and tellers affects attitudes, making them switch to other banks. A detailed examination shows that savings, as well as demand and time deposits, have different characters. Current account customers aim to facilitate their business transactions by focusing on transfer speed, ease of deposit, and clearing facilities. Conversely, savings customers prioritize the convenience of cash withdrawals by focusing on the quality of teller services and the number of easily accessible ATMs. Furthermore, deposit customers own idle funds (not immediately used) and focus on the funds' safety and profit-sharing.

Savings customers are divided into two groups based on the desire to open an account. In this research, 'Voluntary Customer' is less sensitive to the decline in service quality. This is because service quality is considered good at the beginning of being a customer.

One banking service that is the corporation's choice is payroll services, which help corporate customers distribute salaries to employees. This policy demands that all employees of corporate customers should have a savings account at the Bank. However, some employees do not have a savings account at the designated Bank and need to open a new account. This group is referred to as 'Forced Customers' because they disagree with the decision and are usually apathetic and easily dissatisfied. Consequently, their dissatisfaction is usually addressed by taking all salaries and transferring to their account or not actively transacting. Alternatively, in extreme cases, money is taken and kept at home. 
This difference is the basis for sorting savings customers into two groups due to differences in satisfaction factors.

The purpose of saving is to anticipate ignorance in the future. Shaykh Muhammad bin Salih al Utsaimin stated that saving for future calamities is not reprehensible, provided the obligation of property, whether zakat or otherwise, has been properly fulfilled"6. Furthermore, Al-Imam al-Hasan al-Basri rahimahullah once reminded: "May Allah have mercy on a person that seeks lawful wealth to spend it sufficiently and sets aside the excess for their poor days and when need it."7

\section{Customer Satisfaction}

Customer satisfaction is essential for bank management because customer retention is cheaper than new member acquisition. When customers are satisfied, they survive (not switch to others) and remain loyal, building a positive image and word of mouth.

Kotler and Keller defined satisfaction as pleasure or disappointment arising from comparing the perceived performance of a product or result against their expectations". ${ }^{8}$ In this case, when customers are satisfied when their expectations match the results obtained. Similarly, they are satisfied when the results exceed expectations and vice versa. Therefore, the research hypothesis is: There is a difference in satisfaction between 'Forced Customers' and 'Voluntary Customers.'

${ }^{6}$ Syaikh Muhammad bin Shalih al Utsaimin, Tafsir Juz Amma pg 320, in https://pengusahamuslim.com/3345-menabung-dalam-timbangan-1775.html. Accessed on14 July 2019.

7 Al-Imam al-Hasan al-Bashri, riwayat Ath-Thabari dalam https://pengusahamuslim.com/3345-menabung-dalam-timbangan-1775.html. Accessed on 14 July 2019.

8 Kotler, Philip and Kevin Lane Keller, Manajemen Pemasaran, Terj. Bob Sabran, Volume 1 Jakarta: Penerbit Erlangga, 2009, pg 139 . 


\section{RESULTS AND DISCUSSION}

\section{Population and Sampling}

The research population comprised the customers of Islamic Banks in the Special Region of Yogyakarta, including Bank Syariah Mandiri, BNI Syariah, BRI Syariah, BPD Syariah, Bank Muamalat, Bank BTN Syariah, CIMB Syariah, Danamon Syariah and Bukopin Syariah.

Snowball sampling was used to select samples using the Slovin formula ${ }^{9}$ by assuming an infinite population and the error rate of $10 \%$ because it is the social behavior research that does not require high accuracy. The minimum number of samples required is 100 . Based on the rate of return, 500 copies of the questionnaire were physically distributed. The answers of Islamic Bank customers that fulfilled the processing requirements were only 394 copies. Some answers to the questionnaire could not be processed because they were incomplete. Another reason is that all questions were answered with agreed answers without addressing the main questionnaire. The questionnaire was also distributed via the google drive link besides the physical delivery to Islamic Bank customers. The data obtained were tested and explained descriptively analytically.

Table 1 shows the composition of the questionnaire distribution:

Table 1. Questionnaire Distribution

\begin{tabular}{|l|r|r|}
\hline Description & \multicolumn{1}{|l|}{ Total } & Percentage \\
\hline Questionnaire distributed & 500 & \\
\hline Questionnaire that does not return & 108 & 21.60 \\
\hline Returning Questionnaire & 392 & 78.40 \\
\hline Questionnaire with incomplete answers & 47 & 9.40 \\
\hline
\end{tabular}

${ }^{9}$ Syamsul Hadi dan Widyarini, Metodologi Penelitian Untuk Manajemen dan Akuntansi, Yogyakarta: Penerbit Ekonisia, 2009, pg 61. 
Customer Saving Satisfaction Viewed from the Customer's Perspective...

\begin{tabular}{|l|r|r|}
\hline Good physical questionnaire & 345 & 69.00 \\
\hline Questionnaire via google drive & 49 & 9.80 \\
\hline Questionnaire analyzed & 394 & 78.80 \\
\hline
\end{tabular}

Source: Data processed, 2020.

Table 2 shows the names of Islamic banks and details of the customer samples:

Table 2. Name of Islamic Bank Chosen by Respondents

\begin{tabular}{|l|r|r|}
\hline Bank Name & Total (people) & Composition (\%) \\
\hline Bank Syariah Mandiri (BSM) & 130 & 32.99 \\
\hline Bank Muamalat & 94 & 23.86 \\
\hline Bank BNI Syariah & 85 & 21.57 \\
\hline Bank BRI Syariah & 42 & 10.66 \\
\hline Bank BPD Syariah & 28 & 7.11 \\
\hline Bank BTN Syariah & 7 & 1.78 \\
\hline Bank Bukopin Syariah & 5 & 1.27 \\
\hline Others & 3 & 0.76 \\
\hline Total & 394 & 100.00 \\
\hline
\end{tabular}

Source: Data processed, 2020.

Table 2. shows the order of Islamic Bank customers, starting from the largest to fourth, including BSM, Bank Muamalat, BNI Syariah, and BRI Syariah. The respondents' composition is close to the scale of Islamic banks in Indonesia. It shows that the largest Islamic banks are Mandiri Syariah Bank, Muamalat Bank, BRI Syariah Bank and followed by BNI Syariah Bank ${ }^{10}$. Table 3 shows the respondents' composition of Islamic banks in Indonesia.

${ }^{10}$ Financial Services Authority (OJK), Statistik Perbankan Syariah, 2018, 5. 
Table 3. Desire to Save at Islamic Bank (BSM, Muamalat, BRI Syariah and BNI Syariah)

\begin{tabular}{|c|c|c|c|c|c|c|c|c|}
\hline \multirow{2}{*}{$\begin{array}{c}\text { Desire to } \\
\text { Saving }\end{array}$} & \multicolumn{2}{|c|}{ BSM } & \multicolumn{2}{c|}{ Muamalat } & \multicolumn{2}{c|}{ BNI Syariah } & \multicolumn{2}{c|}{ BRI Syariah } \\
\cline { 2 - 10 } & People & $\%$ & People & $\%$ & People & $\%$ & People & $\%$ \\
\hline Want to save & 94 & 72.31 & 31 & 32.98 & 62 & 72.94 & 30 & 71.43 \\
\hline Forced & 33 & 25.38 & 59 & 62.77 & 18 & 21.18 & 4 & 9.52 \\
\hline Installment & 3 & 2.31 & 4 & 4.26 & 5 & 5.88 & 8 & 19.05 \\
\hline Total & 130 & 100 & 94 & 100 & 85 & 100 & 42 & 100 \\
\hline
\end{tabular}

Source: Data processed, 2020.

Table 3 shows that more than $70 \%$ of customers save at Islamic banks out of their own volition. In comparison, $62.77 \%$ of customers at Bank Muamalat open a savings account after being compelled by the workplace for salary receipts. These data show that the collaboration between Bank Muamalat and various agencies in Yogyakarta has successfully gathered many customers. Therefore, Bank Muamalat management should ensure the customers do not switch to other banks when the collaboration is complete. About $19.05 \%$ of BRI Syariah Bank customers save because of the installment factor. This shows that BRI Syariah Bank has the highest financing customers compared to other Islamic banks. Furthermore, it positions itself as a funding bank, while other banks are fund-raising areas in Yogyakarta.

The samples of Islamic Bank customers comprises 190 males (48.22\%) and 204 females (51.78\%). The relatively small (3.55\%) difference indicates a balanced composition of male and female respondents. This means that the research results are not genderbiased. Furthermore, a review based on age shows that 315 respondents (79.94\%) are under 45 years and considered productive. These young people enjoy adding knowledge by studying religion in a scientific context, and their curiosity is greater than older people. In contrast, older people are more religious, solemn (khusnudzon), and easily accept information from various sources. 
Ignorance about the contract or akad, especially for young people as customers of Islamic (Muslim) banks, is unusual. Data on 21 to 24 years old show that almost $30 \%$ of customers do not know their savings contract. Therefore, the older a person is, the less likely they focus on the savings contract, as seen from the contract ignorance of $40 \%$. This indicates there is something wrong, meaning that the community needs intense education to reduce the ignorance about the contract. Education is necessary to eliminate the wrong perception because the contract is the beginning of buying and selling activities or debts agreed upon by both parties. Furthermore, knowing the contract makes Islamic Bank customers determine the possible outcomes (additional funds) from savings in a certain period.

Most customers with no knowledge about the contract are in the Bank Muamalat by $62.77 \%$ as 'Forced Customers.' This shows that the cooperation between the Bank and certain institutions does not consider education for employees or prospective customers. On the contrary, the Bank only focuses on increasing customers without considering the rights and obligations. This needs to be followed up because the difference in the contract causes disparities in the rights and obligations of the customer and the Bank's management.

Of all the respondents, $324(82.23 \%)$ have an undergraduate and doctoral education, while the rest are high school graduates. Respondents with higher education levels are expected to conduct everything more structurally, measurably, and logically, making the data valid. However, this education does not directly impact customer knowledge of savings contracts.

The eight respondents (32\%) with Doctoral Program education level did not know about the savings contract, and the reason was not sought further in this research. Therefore, more in-depth research is needed to uncover the reasons for this ignorance. This is 
interesting because of the limited knowledge on voluntarily opening a savings account at an Islamic Bank. Furthermore, 36 respondents $(24.66 \%)$ with a Master Program education level did not know the savings contract, of which 24 stated that they were forced. The details include 15 people saving at Bank Muamalat (due to agency collaboration), while 9 become customers due to the consequences of taking financing.

The facts on education level, ignorance of contracts, and reasons for opening savings show that savers are 'forced' not to care about the contract for their savings. This means that knowledge about savings contracts is still low, though it is a prerequisite for economic transaction in an agreement. Respondents' answers about the contracts chosen by customers include 211 (53.55\%) for Mudharabah, $57(14.47 \%)$ for Wadiah, while 126 (31.98\%) do not know the contract. This shows that almost one-third of customers do not know the contract, which should not logically happen. The two types of contracts carried out by Islamic banks are mudharabah and wadiah. Therefore, the prospective customer should choose the contract because it is their right and becomes an arbitrary action when determined by the Bank.

Savings is the surrender of customer funds to the Bank within a certain period and being taken back at some point. Based on this concept, savings are grouped into Mudharabah and Wadiah. The Mudharabah relationship is the handing over of funds to the Bank for management to bring outcomes. In contrast, Wadiah is kept with no outcomes, and the owner cares for the funds deposited.

The customer's ignorance of the chosen contract when opening a savings account damages the transaction. This is because Akad or contract is a pillar to be fulfilled in a transaction. According to 
Achmad Warson Munawwir, the contract 11 concludes or binds ${ }^{12}$. Terminologically, it is an agreement between two or more parties regarding certain legal acts. ${ }^{13}$ Therefore, transactions without a contract mean the bond between the saver and the Bank does not exist, making it null and void.

According to the agreement, savings transactions are debt from the Bank because it should return the funds to the customer in due time. The Qur'an Surah Al Baqarah verse 282 teaches how to write transactions and impose people in debt. The writing should be known by at least two male witnesses or one male and two females: And let the one upon whom is the truthful duty of payment (the debtor) dictate, and let him be pious to Allah his Lord. (QS. Al-Baqarah: 282). Based on the verse, Tafsir Ibn Kathir explained that the person in debt dictates what must be written without reducing its value. ${ }^{14}$.

When they save into an Islamic Bank, it becomes the debtor and should record the debt to the customer. This requirement has been fulfilled by the Bank in the savings book. However, the basic contract or agreement used as a reference for placing the savings signed jointly between the Islamic Bank and the customer has not been executed. Moreover, there is no contract signature during the opening of a savings account. When this is carried out, the rights and obligations of the customer and the Bank become visible, allowing the customer to know the contract.

The management of Islamic Banks has never considered the obligation to be witnessed in a contract. Formally, Islamic banks complete with witnesses only show contracts on financing but no

11 Achmad Warson Munawwir, Kamus Al-Munawwir (Yogyakarta: Pesantren Krapyak, t.t.), 1023.

12 Achmad Warson Munawwir, Kamus Al-Munawwir (Yogyakarta: Pesantren Krapyak, t.t.), 1023.

${ }^{13}$ Compilation of Sharia Economic Law Article 20 paragraph (1)

14 Ibnu Katsir, Tafsir Ibnu Katsir, t.t., 191 
information on savings or deposit contracts. The deposit slips state that the profit-sharing ratio is without any witnesses.

There is a need to fulfill the contract requirements as desired by QS. Al Baqarah 282. This requires the Indonesian Ulema Council to issue a fatwa requiring Islamic banks to follow the Qur'an instructions, not only to fulfill the law. The applicable conventional and Islamic banking laws do not regulate contract witnesses in funding cases. Respondents become 'Forced Customer' when their salaries are transferred to the account at Islamic Banks. Therefore, this term is used for customers that open Bank accounts at the request of the Institution. Table 4 shows information about the contracts used by Islamic Banks customers.

Table 4. 'Forced Customer' Contract

\begin{tabular}{|c|c|c|}
\hline Forced Customer' Contract & Total (people) & Composition (\%) \\
\hline Mudharabah & 78 & 53.06 \\
\hline Wadiah & 11 & 7.48 \\
\hline Do not know & 58 & 39.46 \\
\hline Total & 147 & 100.00 \\
\hline
\end{tabular}

Source: Data processed, 2020.

Table 4. shows that $60.54 \%$ of 'Forced Customers' know the contract when opening a savings account. This shows that they try to understand more about their savings products. Furthermore, the customer opens a savings account and learns the consequences related to future compensation. However, $39.46 \%$ of customers did not know the savings contract due to ignorance. Alternatively, it could be assumed that the operational activities of saving at an Islamic and Conventional Bank are the same.

As many as $31.98 \%$ (126 people) of customers did not know the contract when opening a savings account. In comparison, $50.79 \%$ or 64 respondents stated they wanted to save out of their own volition. Furthermore, $44.44 \%$ (56 respondents) stated they saved because they 
were forced, while $4.76 \%$ saved to pay in installments. Therefore, it is interesting to review the data about customers that do not know the savings contract. It is illogical when they become customers to save at an Islamic Bank without knowing the contract. They desire to save without understanding the contract, though it is a determinant of rights and obligations. However, this research does not ask why the respondent does not know the contract. Therefore, further research is needed to uncover the motivation in this group. The 'Forced Customer' group should pay loan installments, which is tolerable because they aim to facilitate transactions.

Customers conducting transactions once a month accounts for $23.60 \%$, while those accessing bank services once or twice a month are $21.83 \%$. This indicates that the transaction involves taking consumption funds or transferring them to another bank. Moreover, $86.29 \%$ of customers indicated they did not use Islamic bank savings as their main account. As many as $27.16 \%$ of customers often transact using Islamic bank savings, while $2.54 \%$ were unwilling to answer questions. The amount of savings in millions of rupiah supports data analysis, where 102 customers $(25.89 \%)$ have never made savings transactions independently. Additionally, 145 customers (36.80\%) transacted once a month, while $27.16 \%$ made between one and five transactions. Similarly, $7.11 \%$ (28 people) had more than five transactions, while the 12 were unwilling to answer.

The data showed that 287 customers (62.69\%) never or only save a little, using savings to receive salaries.

Table 5. Reasons for Opening a Savings Account

\begin{tabular}{|c|c|c|}
\hline Reasons for Opening a Savings Account & Total (people) & Composition (\%) \\
\hline Want to save & 247 & 62.69 \\
\hline Forced & 124 & 31.47 \\
\hline Installment & 23 & 5.84 \\
\hline Total & 394 & 100.00 \\
\hline
\end{tabular}

Source: Data processed, 2020 
Of all the respondents, $37.56 \%$ stated that they opened a savings account only to receive a salary, while $36.04 \%$ wanted to save. This is in line with the respondent's compulsion to open a savings account. Furthermore, $37.31 \%$ of customers stated they were forced to open a savings account, while the rest expressed a desire to save.

As many as $62.69 \%$ of respondents open a savings account because they want to save. Saving money in the Bank reduces a person's consumption, and they save for various purposes. Similarly, the 'Forced Customers' open an account due to a request from the Institution that reaps the positive benefits. Customers take savings through ATMs because they hope part of their salary money would remain in their savings accounts. In contrast, customers must open a savings account in installments. This is because the bank management easily takes regular installments from the savings to facilitate administration and minimize the risk of debt default. Therefore, they are motivated to fill their savings accounts, especially in preparation for installment payments. This means that forced savings or installment payments have greater benefits.

It is interesting to observe further the opinions regarding customer concerns for Islamic Banks.

Table 6. Sharia Concern for Islamic Banks

\begin{tabular}{|c|c|c|}
\hline Concern about Sharia & Total (people) & Composition (\%) \\
\hline Khusnudzon & 176 & 44.67 \\
\hline Believe in Sharia & 83 & 21.07 \\
\hline Consequences of Muslims & 46 & 11.68 \\
\hline Does not matter & 37 & 9.39 \\
\hline There is no other choice & 31 & 7.87 \\
\hline Do not answer & 21 & 5.33 \\
\hline Total & 394 & 100.00 \\
\hline
\end{tabular}

Source: Data processed, 2020 
As many as 83 respondents $(21.07 \%)$ believe that the operational activities of Islamic banks are in line with sharia, implying low public confidence in Islamic banking. Therefore, the management should convince customers or the public, especially Muslims. Moreover, the answers of 176 respondents $(44.67 \%)$ were only devoted to sharia, indicating that they did not know the real conditions. As many as $11.68 \%$ chose Islamic Banks due to consequences as Muslims, without demanding more concrete evidence. This means that they use Islamic banks due to force. Also, some respondents do not care about the Sharia of Islamic Banks because they perceive no operational difference between them and Conventional Banks.

This community conclusion is not excessive because Islamic Banks replace interest with profit-sharing without sufficient support for using the term. Consequently, the public lacks information that profit sharing is different from interest. Savings with a sharia bank mudharabah contract provide monthly profit sharing according to a predetermined ratio. The distribution was based on the estimated monthly profit. However, no adjustment was made to the actual profit after the audit at the end of the year. Additionally, no Islamic Bank has re-calculated the profit-sharing based on actual profits or results. A correct end-year profit or loss calculation adjusts the savings taken before the end of the current year by increasing profit sharing or vice versa. This calculation is a difference between interest and profit-sharing. However, since this has not been carried out, some people still perceive no difference.

Table 7. Reasons for Choosing Islamic Banks for Savings

\begin{tabular}{|c|c|c|}
\hline Reason & Total (people) & Composition (\%) \\
\hline Own Will & 202 & 51.27 \\
\hline Friend's suggestion & 32 & 8.12 \\
\hline Advertisement & 13 & 3.30 \\
\hline
\end{tabular}


Widyarini E Samsul Hadi

\begin{tabular}{|c|c|c|}
\hline Requested & 135 & 34.26 \\
\hline Others & 12 & 3.05 \\
\hline Total & 394 & 100,00 \\
\hline
\end{tabular}

Source: Data processed, 2020.

The choice of customers saving at an Islamic Bank out of their own volition reached $51.27 \%$, indicating their high awareness as Muslims. Furthermore, policy on Cooperation between Institutions and Islamic Banks is mutually beneficial. For the Institution, the policy practically reduces the risk of taking large amounts of money and employees working in the finance department to pay salaries. This increases the number of customers and funds. The strategy regarding customers opening accounts for salary transfers $(34.26 \%)$ is a development effort of Islamic banks. Cooperation between Institutions is carried out for personal selling activities. The success of the Islamic Bank leadership to convince other institutions to cooperate is based on trust, with both parties benefiting from each other. Also, the reason for suggestions from friends $(8.12 \%)$ means that they open accounts at certain Islamic banks because of positive word of mouth from loyal customers. Therefore, although the value is still low, the satisfaction level is necessary because only satisfied customers carry out the positive word of mouth. The low percentage means that the Bank should find out the reasons for the management to make changes to their strategy, ensuring customer improvement.

Effective advertising activities impact the interest in becoming a customer, though it only motivates by $3.30 \%$. This shows that the management does not effectively communicate the Islamic Bank's operational activities to motivate others to save. Therefore, the management should review its promotion strategy to overcome the weaknesses and increase the Muslims' interest in saving. Data regarding promotional activities from Islamic Banks is accessible through the web, brochures, or leaflets. 
The Islamic Bank's Web regarding the message content needs improvement. Also, a detailed explanation is needed to clarify the differences in operational activities between conventional and Islamic banks. This information transparency is expected to attract new potential customers as khusnudzon and believe that the Islamic Bank is syar'i.

The brochure contains general information about product offerings and information deemed by management as required by customers. However, it is only placed in the office space of the Islamic Bank, meaning that customers interested would take the brochure. This method is ineffective because it should be distributed actively to potential customers. For instance, it should be distributed at recitation events and in-house social gatherings with many Muslim members. Furthermore, when possible, the brochure should be distributed by explaining the Islamic banking operational activities. Therefore, the brochure contents should be synchronized with information about the differences between the operational activities of conventional and Islamic banks.

This research uses a different test between 'Forced Customer' and 'Voluntary Customer' to determine the significance of the difference. A significant difference means that a different service model should be carried out. Moreover, the difference is only in the service because the applicable rules apply are similar. However, services could be different, especially in communicating. This is because 'Voluntary Customer' already has a positive image initially, while 'Forced Customer' has a different image because it begins with compulsion. Therefore, a different approach is needed for the 'Forced Customer' to feel satisfied and happy as a customer of an Islamic Bank. 


\section{Validity Test}

This test determines the validity of the questionnaire, whether it has asked the right questions. The validity of each statement was tested with a construct (Construct Validity) and a statistical approach. The construct approach uses theoretical elaboration, while statistical validity uses item tests. ${ }^{15}$

Table 8. Validity Test Results

\begin{tabular}{|l|l|l|l|}
\hline Statement & $\mathrm{r}^{2}$ & $\mathrm{t}$ & sig t \\
\hline Satisfaction1 & 0.74433 & 22.0678 & $9.9 \mathrm{E}-71$ \\
\hline Satisfaction2 & 0.67715 & 18.2196 & $3.6 \mathrm{E}-54$ \\
\hline Satisfaction3 & 0.78259 & 24.8892 & $1.1 \mathrm{E}-82$ \\
\hline Satisfaction4 & 0.78334 & 24.9513 & $5.8 \mathrm{E}-83$ \\
\hline Satisfaction5 & 0.75932 & 23.1037 & $3.7 \mathrm{E}-75$ \\
\hline Satisfaction6 & 0.34152 & 7.19422 & $3.2 \mathrm{E}-12$ \\
\hline
\end{tabular}

Source: Data processed, 2020.

Table 8 shows that all statements have a significance value of $t$ below $1 \%$, meaning they are statistically valid. ${ }^{16}$.

\section{Reliability}

The reliability test was performed using Chronbach Alpha. The satisfaction test obtained a CA value $=0.8345$, indicating that the measurement of variables is reliable.

\section{Customer Satisfaction}

Consumer satisfaction is obtained by Islamic Bank customers for the services received. Table 9 shows the level of consumer satisfaction of the respondents:

15 Syamsul Hadi, Membuat Kuesioner, (Yogyakarta: PT Ekonisia, 2018), 80

16 Ibid. 
Customer Saving Satisfaction Viewed from the Customer's Perspective...

Table 9. Descriptive Statistics on Satisfaction

\begin{tabular}{|l|l|}
\hline Average & 3.195652174 \\
\hline Varian & 0.845565069 \\
\hline Total Data & 394 \\
\hline Maximum & 5 \\
\hline Minimum & 0 \\
\hline
\end{tabular}

Source: Data processed, 2020.

Table 9 shows that the average satisfaction is only 3.19 out of 5 , with a variance of 0.85 . This means that the data obtained is homogeneous, supported by the variance value of only $25.6 \%$ of the average. Additionally, the value of 3.19 indicates that Islamic Bank customers feel low satisfaction. This is because it only increases by 0.19 from neutral and is felt by all customers due to the data's homogeneity.

Table 10. Distribution of Customer Satisfaction Value

\begin{tabular}{|l|c|c|}
\hline Option & Total & $\%$ \\
\hline Very Dissatisfied & 51 & 12.9 \\
\hline Not satisfied & 77 & 19.5 \\
\hline Neutral & 167 & 42.4 \\
\hline Satisfied & 98 & 24.9 \\
\hline Very satisfied & 1 & 0.3 \\
\hline Total & 394 & 100 \\
\hline
\end{tabular}

Source: Data processed, 2020.

Table 10 shows that only one respondent is very satisfied with the services of Islamic Banks. Also, $42.4 \%$ of respondents have a neutral opinion, while $32.4 \%$ firmly stated not satisfied or very dissatisfied. The problem with high satisfaction is homework for the management of Islamic Banks. The management should take action to enjoy their satisfaction to the fullest. Furthermore, it should improve service to make customers satisfied. 


\section{Satisfaction Difference Test}

An Islamic Bank customer has voluntary and forced reasons or causes. Several reasons support the desire to become a customer voluntarily. These include the consequences of being a Muslim, wanting to avoid usury, and believing in the syar' $i$ of the Bank. In contrast, the reasons supporting forced customers include simplifying the installment process for financing products. Also, there could be a collaboration between the Islamic Bank and the office, making salaries sent through the Bank. These two reasons have different meanings of 'voluntary' and 'forced,' resulting in different customer satisfaction levels with the Islamic Bank.

'Voluntary Customers' are insensitive to factors supporting their satisfaction due to their desires. In contrast, 'Forced Customers' are more sensitive to factors supporting their satisfaction. This is due to the compulsion by the Institution to open an account at the Islamic Bank. As a result, the customer feels a small management error, and the assessment is less objective. Therefore, a two-average difference test was conducted using the Microsoft Excel program to determine the difference.

The hypothesis statements are:

$\mathrm{H}_{0}$ : There is no difference between 'Voluntary Customers' and 'Forced Customers' satisfaction.

Table 11.

Calculation Results of Two Average Difference Test

\begin{tabular}{|l|l|l|}
\hline \multicolumn{3}{|l|}{-Test: Two-Sample Assuming Unequal Variances } \\
\hline & Voluntary & Forced \\
\hline Mean & 3.277328 & 2.993197 \\
\hline Variance & 0.77429 & 1.117153 \\
\hline Observations & 247 & 147 \\
\hline Hypothesized Mean Difference & 0 & \\
\hline
\end{tabular}


Customer Saving Satisfaction Viewed from the Customer's Perspective...

\begin{tabular}{|l|l|l|}
\hline$D f$ & 265 & \\
\hline$t$ Stat & 2.742383 & \\
\hline $\mathrm{P}(\mathrm{T}<=\mathrm{t})$ one-tail & 0.003258 & \\
\hline$t$ Critical one-tail & 1.650624 & \\
\hline$P(T<=t)$ two-tail & 0.006515 & $* * *$ \\
\hline$t$ Critical two-tail & 1.968956 & \\
\hline
\end{tabular}

Source: Data processed, 2020.

***) Significant below $1 \%$

This research uses a 5-point Likert scale, where the average value of satisfaction around 3 means they are satisfied. The 'Forced Customers' satisfaction level of 2.993197 was lower than 'Voluntary Customers,' which had 3.277328. This is natural because 'Forced Customers' hope for good service. Therefore, a slight deficiency in service decreases satisfaction. However, this is different from 'Voluntary Customers' because they are more satisfied and accept the services. The different tests show a two-tail $P(T<=t)$ of 0.006515 , meaning it is significant. Therefore, there is a strong difference between the satisfaction of 'Forced Customers' and 'Voluntary Customers.'

Table 12.

Descriptive Statistics on Voluntary and Forced Group Satisfaction

\begin{tabular}{|l|l|l|}
\hline & Voluntary & Forced \\
\hline Mean & 3.277328 & 2.993197 \\
\hline Standard Deviation & 0.879937 & 1.056954 \\
\hline Sample Variance & 0.77429 & 1.117153 \\
\hline Minimum & 0 & 0 \\
\hline Maximum & 4.833333 & 5 \\
\hline Count & 247 & 147 \\
\hline
\end{tabular}

Source: Data processed, 2020.

The satisfaction of the two groups has fairly high variability. The lowest value for both groups is 0 (zero), meaning they show no 
satisfaction as Islamic Bank customers. Therefore, the low value indicates that customers are very dissatisfied with what they have received. The highest scores for the 'Voluntary Customer' and 'Forced Customer' groups were 4.833 and 5.0, respectively. This is supported by the difference in variance between the voluntary group with 0.77429 and the forced group with 1.11715. Moreover, the high difference in variance indicates that 'Voluntary Customers' have a more homogeneous satisfaction.

Table 13.

Satisfaction Frequency Distribution

\begin{tabular}{|l|r|r|r|r|}
\hline \multirow{2}{*}{ Satisfaction } & \multicolumn{3}{|l|}{ Voluntary } & \multicolumn{2}{l|}{ Forced } & \\
\cline { 2 - 5 } & Frequency & Percentage (\%) & Frequency & Percentage (\%) \\
\hline 0 to 1 & 4 & 1,62 & 7 & 4,76 \\
\hline 1,001 to 2 & 26 & 10,53 & 27 & 18,37 \\
\hline 2,001 to 3 & 51 & 20,65 & 31 & 21,09 \\
\hline 3,001 to 4 & 140 & 56,68 & 69 & 46,94 \\
\hline 4,001 to 5 & 26 & 10,53 & 13 & 8,84 \\
\hline Total & 247 & 100,00 & 147 & 100,00 \\
\hline
\end{tabular}

Source: Data processed, 2020.

Table 13 shows very low satisfaction of one or lower in the 'Voluntary Customer' group by $1.62 \%$, and is considered outlier data and ignored. In the 'Forced Customer' group, $4.76 \%$ felt very dissatisfied, and the value cannot be ignored because it is close to $5 \%$.

Table 13 also shows respondents with high satisfaction of three and more on are 'Voluntary Customers' with $67.21 \%$, while 'Forced Customers' have $55.78 \%$. This shows that the components of satisfaction between the two groups are different. Therefore, they should be separated to determine the factors driving customer satisfaction. Also, the compulsion to become a customer should only be included in the model as an independent variable. When this is not carried out, it would only produce the significance level, 
meaning that this variable affects customer satisfaction or vice versa. Additionally, the research would not show what variables determine each group's satisfaction.

No research has examined bank customer satisfaction by distinguishing between volunteer and forced customers. The only research found examined the difference in satisfaction between customers of Islamic and Commercial Banks. ${ }^{17,18}$ Therefore, the results cannot be used as a reference or comparison with this research. Furthermore, research on customer satisfaction does not separate saving customers from financing, though the two groups have different behavior patterns. The saving customer owns the funds and easily transfers their funds to another bank when not satisfied. On the contrary, financing customers are dependent on financial assistance, resulting in the acceptance of all treatment from employees. Unpleasant service from employees is taken for granted, and switching to another bank due to unsatisfactory treatment is difficult, especially for people with poor credit standing. The difference in these characteristics affects the model for forming customer satisfaction.

Further research is suggested to separate between saving and financing customers. Also, it is necessary to separate saving customers into forced and voluntary to obtain comparable results. However, there is no need to separate financing customers because

17 Sarwani, Andry Herawati dan Liling Listyawati, Analisis Perbandingan Kepuasan Nasabah Bank Syariah Dengan Bank Umum Konvensional Di Surabaya, Univ. Dr Soetomo Surabaya, http://repository.unitomo.ac.id/744/, 2017, accessed on February 16, 2019.

18 Yudi Siyamto, Preferensi Kepuasan Nasabah Bank Umum Syariah Dan Bank Umum Konvensional Dalam Perspektif Fuzzy Carter Dan Fuzzy Servqual Di Surakarta Tahun 2015, IAIN Surakarta, eprints.iain-surakarta.ac.id/25/1 /2015TS0015.pdf., 2015, accessed on February 16, 2019. 
people in debt are forced to fulfill their needs and avoid debt when it is sufficient.

A sensitivity analysis with the variable 'Know the Contract' as a proxy for the customer's knowledge of Islamic Bank operations result in four groups of respondents. These include the Voluntary Customers that Know and Do Not Know the Contract and the Forced Customers that Know and Do Not Know the Contract. Their knowledge about the contract and Islamic Banks' operations impact their expectations and satisfaction. Customers that know the differences have high expectations for the operationalization of Islamic banks. Therefore, their satisfaction is affected when they receive different facts.

The Sensitivity Analysis performed with Microsoft Excel is shown as follows:

Table 14. Customer Satisfaction Level

\begin{tabular}{|l|l|l|l|}
\hline $\begin{array}{l}\text { Know the } \\
\text { contract and } \\
\text { forced }\end{array}$ & $\begin{array}{l}\text { Do not know the } \\
\text { contract and } \\
\text { forced }\end{array}$ & $\begin{array}{l}\text { Know the } \\
\text { contract and } \\
\text { voluntary }\end{array}$ & $\begin{array}{l}\text { Do not know the } \\
\text { contract and } \\
\text { voluntary }\end{array}$ \\
\hline 3.166666667 & 2.954022989 & 3.280260708 & 3.075980392 \\
\hline
\end{tabular}

Source: Data processed, 2020.

Table 15. t-Test Significance

\begin{tabular}{|c|c|c|c|}
\hline & $\begin{array}{c}\text { Do not know } \\
\text { and forced }\end{array}$ & $\begin{array}{c}\text { Know and } \\
\text { voluntary }\end{array}$ & $\begin{array}{c}\text { Do not know and } \\
\text { voluntary }\end{array}$ \\
\hline Know and forced & 0.225390016 & 0.357816227 & 0.563215432 \\
\hline $\begin{array}{c}\text { Do not know and } \\
\text { forced }\end{array}$ & 0.022971246 & 0.480080907 \\
\hline $\begin{array}{c}\text { Know and } \\
\text { voluntary }\end{array}$ & & 0.113953495 \\
\hline
\end{tabular}

Source: Data processed, 2020.

Tables 14 and 15 show that customer satisfaction in each quadrant is not different because it has a significance value greater than $10 \%$. The difference in satisfaction between customers that did not know the contract and forced, and those that know the contract 
and voluntary has a significant value of $2.2 \%$. Therefore, it is included in the moderately significant group. This difference is very logical because these two customers are extreme groups.

The Islamic Bank customers are forced by the Institution and do not know the contract used to open a savings account. Ignorance of the contract shows that this group does not care about its operations. Also, it does not consider the difference between Wadiah and Mudharabah contracts in savings. The main difference between the two contracts is the profit-sharing on the balance of funds deposited in the savings book. Therefore, this group is indifferent to Islamic Bank products and treats savings as a medium to earn a salary, resulting in low satisfaction levels.

Voluntary customers that know the contract understand Islamic Bank products, and their satisfaction increases with an increase in service quality. Although there are differences in satisfaction, the overall satisfaction is still very low. The highest satisfaction is 3.2 out of 5, which is still very low. Therefore, Islamic bank management should increase customer satisfaction to make them more comfortable. When the corrective policy is not implemented, customers would treat their savings account only as a means of receiving salaries and transfer money at the first opportunity. Banks only benefit from many customers but not from depositing funds from 'Forced Customers.'

\section{CONCLUSION}

The conclusion of this research is Islamic Bank customer satisfaction is still very low. There is a significant difference between the satisfaction of 'Voluntary Customers' and 'Forced Customers.' There is a significant difference between the satisfaction of 'Voluntary Customers that know the contract' and 'Forced Customers that do not know the contract.' There is no significant difference 
between the satisfaction of 'Voluntary Customers that know the contract' and 'Voluntary Customers that do not know the contract.' There is no significant difference between the satisfaction of 'Forced Customer that knows the contract' and 'Forced Customer that does not know the contract.' There is no significant difference between the satisfaction of 'Voluntary Customers that do not know the contract' and the 'Forced Customer that knows the contract.' Customer understanding of the operational concept of Islamic banks is still low. Suggestions given are Islamic banks management should increase customer satisfaction to benefit from saving customers. The management should explain the contract during account opening to prospective customers due to cooperation. Management of Islamic Banks should increase socialization about the differences between Islamic and Conventional Bank operations. The Financial Services Authority (OJK) and the Islamic Economic Community should educate the public on the operational literacy of Islamic banks.

\section{REFERENCES}

Abdillah, Willy dan Jogiyanto HM, Partial Least Square (PLS) Alternatif Structural Equation Modelling (SEM) dalam Penelitian Bisnis, Yogyakarta: Andi, 2015.

Al-Azzam, Abdel Fattah Mahmoud, The Impact of Service Quality Dimesions on Customer Satisfaction: A Field Study of Arab Bank in Irbid City; European Journal of Business and Management vol 7, no 15, 2015

Al-Imam al-Hasan al-Bashri, riwayat Ath-Thabari dalam https://pengusahamuslim.com/ 3345-menabung-dalamtimbangan-1775.html. Diakses 14 Juli 2019.

Awan, Hayat M dan Khuram Shahzad Bukhari, Customer's Criteria for Selecting an Islamic Bank: Evidence from Pakistan, Journal of Islamic Marketing, Vol. 2 No. 1, https:// doi.org/10.1108/17590831111115213, 2011, 14-27, 
Customer Saving Satisfaction Viewed from the Customer's Perspective...

Bawono, Anton, Analisis Atas Perilaku Konsumen Dengan Religiusitas Sebagai Moderating Variable, Disertasi Program Pasca Sarjana UIN Suka Yogyakarta, (tidak dipublikasikan), 2013.

Bisri, Mustofa, Saleh Ritual dan Saleh Sosial, Yogyakarta: Diva Press, 2016.

Budi Purwadi, Riset Pemasaran, Jakarta: Grasindo, 2000.

Engel, F James, Perilaku Konsumen, terj. Budijanto, Jilid 1 dan 2, Jakarta: Bina Aksara, 2012.

Ghozali, Imam, Structure Equation Modeling Method Alternatif dengan Partial Least Square, Semarang: Penerbit Universitas Diponegoro, 2006.

Gujarati, Damodar N., Basic Econometrics, New York: McGraw-Hill Companies, 2004.

Hadi, Syamsul dan Widyarini, Metodologi Penelitian Untuk Manajemen dan Akuntansi, Yogyakarta: Penerbit Ekonisia, 2009.

Hadi, Syamsul, Memanfaatkan Excel Untuk Analisis Statistik, Yogyakarta: Penerbit Ekonisia, 2007.

, Membuat Kuesioner, Yogyakarta: Penerbit Ekonisia, 2017.

Hansemark, Ove C., dan Marie Albinson, Customer Satisfaction and The Retention: The Experiences of Individual Employees, Managing Service Quality, Journal of Service Theory and Practice 14 (1), Emerald Group Publishing Limited, Vol. 14Number 1, 2004, 40-57.

Hashemi, Jafar; Abbasi, Fatemeh, The Impact Of E-Service Quality On Customer Satisfaction, Kuwait Chapter of the Arabian Journal of Business and Management Review Volume: 3, Issue: 6A, 2014, 86-94.

Hoq, Mohammad Ziaul; Nigar Sultana; Muslim Amin, The Effect of Trust, Customer Satisfaction and Image on Customers' 
Loyalty in Islamic Banking Sector, South Asian Journal of Management, Volume: 17, Issue: 1, 2010, 70-93,.

Ibnu Katsir, Tafsir Ibnu Katsir, t.t., 191

Jafar Hashemi dan Fatemeh Abbasi, The Impact of E-Service Quality On Customer Satisfaction, Kuwait Chapter of Arabian Journal of Business and Management Review 3 (6.a). 2014, 86-94.

Jogiyanto H.M, Metodologi Penelitian Bisnis: Salah Kaprah dan Pengalaman-Pengalaman, Yogyakarta: BPFE Yogyakarta, 2007.

Pedoman Survei Kuesioner, Yogyakarta: BPFE Yogyakarta, 2014.

Khaliq, Ahmad, Ghulam Ali Rustam, Michael M.Dent, Brand Preference in Islamic Banking, Journal of Islamic Marketing, Vol.2 No. 1, Emerald Group Publishing Limited 1759-0833, 2011, 74-82.

Kompilasi Hukum Ekonomi Syariah Pasal 20 ayat (1)

Kotler, Philip dan Kevin Lane Keller, Manajemen Pemasaran, Terj. Bob Sabran, Jilid 1 dan 2, Jakarta: Penerbit Erlangga, 2009

Lee, Siew Peng dan Sedigheh Moghavvemi, The Dimesion of Service Quality and Its Impact on Customer Satisfaction, Trust and Loyalty: A Case of Malaysian Banks, Asian Jurnal of Busines and Accounting, 8(2), 2015, 91-101.

Levine, Stephan, Krehbel and Berenson, Statistics for Managers, New Yersey: Prentice Hall, 2008.

Lovelock, Christopher, Jochen Wirzt and Jacky Mussry, Pemasaran Jasa, Manusia, Teknologi dan Strategi, Perspektif Indonesia, Terj. Dian Wulandari dan Devri Barnadi Putera, Jakarta: Penerbit Erlangga., 2011.

Munawwir, Ahmad Warson, Kamus Al-Munawwir, Yogyakarta:

Pesantren Krapyak, t.t. 
Nugroho, Junaidi, Analisis Tingkat Kepuasan Nasabah Bank Syariah BRI Kantor Cabang Yogyakarta, Tesis MM UGM, 2005.

Otoritas Jasa Keuangan (OJK), Statistik Perbankan Syariah, 2018.

Sabiq, Sayyid, Fikih Sunnah, Terj. Abdurrahim dan Masrukhin, Jilid 5, Jakarta: Cakrawala Publishing, 2009.

Sarwani, Andry Herawati dan Liling Listyawati, Analisis Perbandingan Kepuasan Nasabah Bank Syariah Dengan Bank Umum Konvensional Di Surabaya, Univ. Dr Soetomo Surabaya, http://repository.unitomo.ac.id/744/, 2017, diakses 16 Februari 2019.

Sekaran, Uma, Research Method for Business, Terj. Kwan Men Yon, Jakarta: Penerbit Salemba Empat, 2011.

Siyamto, Yudi, Preferensi Kepuasan Nasabah Bank Umum Syariah dan Bank Umum Konvensional dalam Perspektif Fuzzy Carter dan Fuzzy Servqual di Surakarta Tahun 2015, Thesis, IAIN Surakarta, eprints.iain-surakarta.ac.id/25/1 /2015TS0015.pdf. diakses 16 Februari 2019.

Sumarman, Ujang, Perilaku Konsumen, Teori dan Penerapannya dalam Pemasaran, Bogor, Ghalia Indonesia, 2011.

Supranto, Pengukuran Tingkat Kepuasan Pelanggan, Jakarta: Rineka Cipta, 2011.

Syaikh Muhammad bin Shalih al Utsaimin, Tafsir Juz Amma hal 320, dalam https://pengusahamuslim.com/3345-menabungdalam-timbangan-1775.html. Diakses 14 Juli 2019.

Tjiptono, Fandi, Pemasaran Jasa, Prinsip Penerapan, Penelitian, Yogyakarta: Penerbit Andi, 2014.

Widyarini, Pengaruh Langsung Trust, Religiusitas dan Mediasi Perceived Value terhadap Kepuasan Nasabah Penabung, Disertasi Program Pasca Sarjana UIN Suka Yogyakarta, (tidak dipublikasikan), 2020. 
Widyarini \& Samsul Hadi

Zeithaml, Valerie A dan Marie Jo Bitner, Service Marketing, McGraw-Hill (International Edition), 1996. 